\title{
Beetle diversity in fragmented thornscrub and isolated trees
}

\author{
G. Cuéllar-Rodríguez ${ }^{a}$,E. Jurado ${ }^{a *}$ and J. Flores ${ }^{b}$ \\ ${ }^{a}$ Facultad de Ciencias Forestales, Universidad Autónoma de Nuevo León - UANL, AP 41, \\ Carretera Nacional 85, Km 145, Linares, NL, CP 67700, México

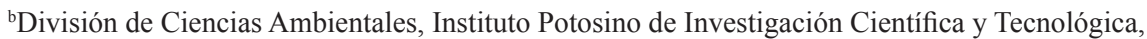 \\ Camino a la Presa San José, 2055, Colonia Lomas 4a. Sección, San Luis Potosí, SLP, CP 78216, México \\ *e-mail: enrique_jurado@hotmail.com
}

Received: July 7, 2015 - Accepted: September 30, 2015 - Distributed: February 28, 2017

(With 3 figures)

\begin{abstract}
Due to land use change mainly for induced agriculture, Tamaulipan thornscrubin northeast Mexico has been cleared and transformed into small patches of vegetation as small as isolated trees surrounded by agricultural fields. In this study, we explored how tree isolation or growing inside a fragment of remnant vegetation influence diversity of coleopterans in two plant species (Prosopis laevigata (Humb. \&Bonpl.exWilld.) M.C. Johnst. (mesquite) and Ebenopsis ebano (Berl.) Barneby (Texas ebony). We found 72 coleopteran morphospecies; fifteen occurred mainly in remnant fragments and ten mainly in isolated trees. There were more insects under isolated mesquites than under those immersed in remnant fragments, while in Texas ebony the highest beetle density for isolated trees coincided with periods of bean and maize in surrounding agriculture.
\end{abstract}

Keywords: coleopterans, vegetation-patches, landscape.

\section{Diversidade de coleópteros em um fragmento do bioma thornscrub e árvores isoladas}

\section{Resumo}

Devido a mudança de uso da terra para induzir principalmente a agricultura, o bioma thornscrub no nordeste México tem sido transformado em fragmentos pequenos como árvores isoladas rodeadas por campos agrícolas. Neste estudo exploramos como o isolamento das árvores influi na diversidade de coleópteros em duas espécies de plantas (Prosopis laevigata (Humb. \& Bonpl.ex Willd) M.C. Johnst. (mesquite) e Ebenopsis ebano (Berl.) Barneby (Texas ebony). Encontramos 72 morfospecies do coleópteros; quinze ocorreram principalmente em fragmentos remanescentes e dez em árvores isoladas. No estudo houve mais insetos nas "mesquite" isoladas do que nos fragmentos remanescentes do bioma thornscrub, enquanto que em "Texas ebony" a densidade alta de coleópteros para árvores isoladas coincidiu com períodos de produção de feijão e milho na agricultura ao redor.

Palavras-chave: coleoptera, paisagem fragmentada, vegetação fragmentada.

\section{Introduction}

Fragmentation of natural vegetation is one of the main causes of extinction risk and reduction in population size and distribution (Fahrig, 2002). Matorral, also known as Tamaulipan thornscrub is the native vegetation to northeastern Mexico and South Texas (Reid et al., 1990a; Foroughbakhch et al., 2013). This vegetation is diverse in woody plants, half of which are thorny (Reid et al., 1990b). Due to land use change for induced grasslands and agriculture, this vegetation has been cleared living behind small fragments and often isolated trees of species with fodder or food value (Jurado et al., 1999, Jurado et al., 2006a, b; Antonio-Nemiga et al., 2008). Two of such species are Prosopis laevigata(Humb. \&Bonpl.ExWilld.)
M.C. Johnst.(mesquite) and Ebenopsis ebano(Berl.) Barneby (Texas ebony). Both species produce high quality wood, fodder and edible pods (Reid et al., 1990b).

Vegetation fragmentation affects species density and diversity (Didhamet al., 1996; Malcolm, 1994; Laurance et al., 1998; Silva et al., 2014). In general, there are fewer species in isolated small fragments than there are in larger fragments or continuous vegetation (Scariot, 1999; Wettstein and Schmid, 1999). A better understanding of landscape composition and spatial configuration of landscape elements and how they affect spillover of functionally important species across managed and natural habitats is needed (Tscharntke et al., 2008). 
In here, we explored how tree isolation or growing inside a fragment of remnant vegetation, influence diversity of associated insects. Insects respond rapidly to environmental changes as they have many life cycles in a short time, when compared to other species such as birds or mammals (Brown, 1997; Hunter, 2002). Coleopterans in particular are easy to sample and relatively easy to identify as families or even morphospecies (Hirao et al., 2008). We hypothesized that species richness and diversity of coleopterans would be lower for isolated trees than for those immersed in remnant fragments.

\section{Material and Methods}

The study area is located in Linares, Nuevo Leon, Mexico (24.49 N, -99.30 E and $337 \mathrm{~m}$ above sea level). The area is relatively flat with gentle slopes and deep vertisol soils (INEGI, 2008).

Trees from two species, Prosopis laevigata (Humb. \& Bonpl.ex Willd) M.C. Johnst. (mesquite) and Ebenopsis ebano (Berl.) Barneby (Texas ebony) were selected in each of two conditions: (i) at least $10 \mathrm{~m}$ inside a remnant fragment and ca. $100 \mathrm{~m}$ away from the nearest fragment inside agricultural fields. Three trees for each species were used in each condition. Trees were similar in height (mesquite: 10.9, Texas ebony: $8.7 \mathrm{~m}$ ), diameter at breast height (mesquite: $36 \mathrm{~cm}$, Texas ebony: $33 \mathrm{~cm}$ ), and crown diameter (mesquite: $9.7 \mathrm{~m}$, Texas ebony: $7.9 \mathrm{~m}$ ). Insects were sampled at the periods with higher insect activity in April, September, November 2009, March and April 2010.

Under each tree 8 pitfall traps with water and detergent were used. Pineapple and tuna were used as attractants. Traps were left for 48 hours during each sampling event. Insects were separated and later identified.

There were three trees of each species in agricultural fields (considered as isolated) $(n=6)$, and three trees of each species inside a thornscrub fragment $(n=6)$. There were five collecting dates.

Isolated trees were surrounded by agriculture. Fields were not in use during sampling in April 2009 and March 2010. During April 2010 corn was grown. In September and November 2009 fields were sowed with beans. Sowing was stopped at least $10 \mathrm{~m}$ away from isolated tree canopies.

The results were submitted to one-way analysis of variance to determine differences between tree species and isolation treatments.

\section{Results}

Insect density varied between samples, from 440 individuals in November to 7,771 in April. Across samples 15,845 coleopterans were collected. Insect density was similar between tree species: 8,339 in Texas ebony trees and 7,506 in Mesquites $(\mathrm{F}=0.026$, d.f. $=9, \mathrm{P}=0.875)$. The total number of beetles under isolated trees and those immersed in remnant fragments was also similar
( $\mathrm{F}=0.675$, d.f. $=9, \mathrm{P}=0.435)$. There were 10,077 beetles under isolated trees and 5,768 under trees inside remnant fragments.

There were more insects under isolated mesquites than under those immersed in remnant fragments across sampling dates (April 2009: $\mathrm{F}=9.01$, d.f. $=5, \mathrm{P}=0.03$; September 2009: $\mathrm{F}=16.14$, d.f. $=5, \mathrm{P}=0.01$; November 2009: $\mathrm{F}=11.26$, d.f. $=5, \mathrm{P}=0.02$; March 2010: $\mathrm{F}=154$, d.f. $=5, \mathrm{P}=0.002$; April $2010 \mathrm{~F}=18.36$, d.f. $=5, \mathrm{P}=0.02$ ) (Figure 1).

Number of insects under Texas ebony trees also varied across time (Figure 2). During April 2009 and April 2010 more insects were found in fragments than in isolated trees $(\mathrm{F}=10.21$, d.f.. $=6, \mathrm{P}=0.03$ and $\mathrm{F}=31.7$, d.f. $=5, \mathrm{P}=0.004)$. However in September and November there were more insects under isolated trees $(\mathrm{F}=16.14$, d.f. $=5, \mathrm{P}=0.01$ and $\mathrm{F}=11.23$, d.f. $=5, \mathrm{P}=0.02)$, and similar numbers in March $(\mathrm{F}=0.07$, d.f. $=5, \mathrm{P}=0.79)$ (Figure 2).

Species richness was similar under isolated trees and under trees immersed in remnant vegetation $(\mathrm{F}=2.51$, d.f. $=8, \mathrm{P}=0.39$ ). Out of the 72 morphospecies, 52 occurred in both conditions although with different number of individuals (Figure 3). Four species (Scarabide B, Staphylinidae A, Staphylinidae F and Tenebrionidae G) occurred only in remnant fragments and were not found under isolated trees, Chrysomeidae A and Tenebrionidae A had little representation in isolated trees and thus might be considered as sensitive to fragmentation (Table 1). Five species (Cucujidae A, Histeridae A, Nitidulidae C, Nitidulide G and Scarabidae A) occurred in large quantities under isolated trees and may be favored by human transformed environments (Table 1).

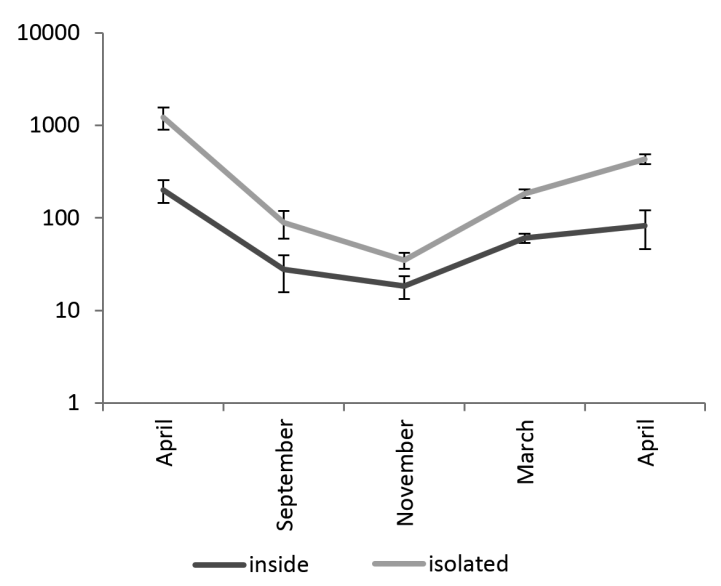

Figure 1. Mean number of coleopteran insects found under mesquites. Total number varied across time but was always higher for isolated mesquites (dark line) than for those growing in remnant fragments (grey line). Each point represents the mean of three trees, error bars are standard deviations. 
In Figure 3 the number of individuals for each morphospecies is plotted for each isolation condition. The amplitude of both curves is similar as the number of species is similar in both conditions. The curve for insects found under isolated trees shows one dominant morphospecies (family Histeridae A), and one co-dominant

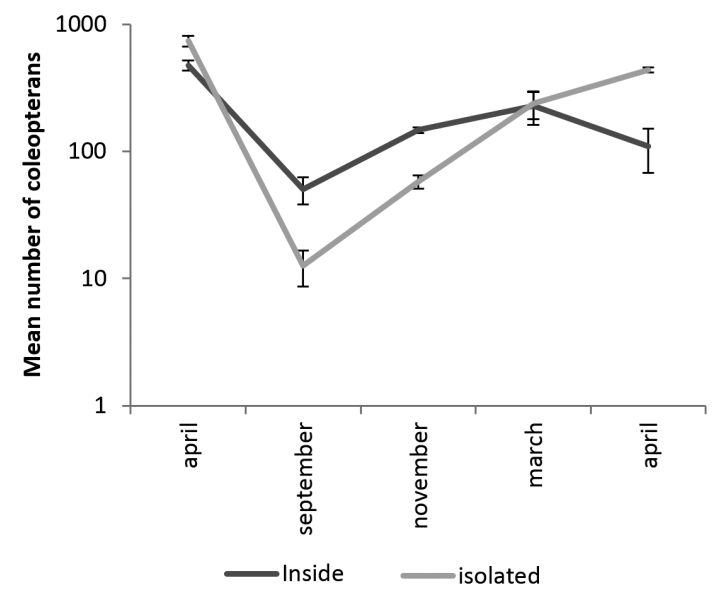

Figure 2. Mean number of coleopteran insects found under Texas ebony trees. Total number varied across time but also between conditions in that it was sometimes higher for isolated trees (dark line) and sometimes higher for trees growing in remnant fragments (grey line). Each point represents the mean of three trees, error bars are standard deviations.

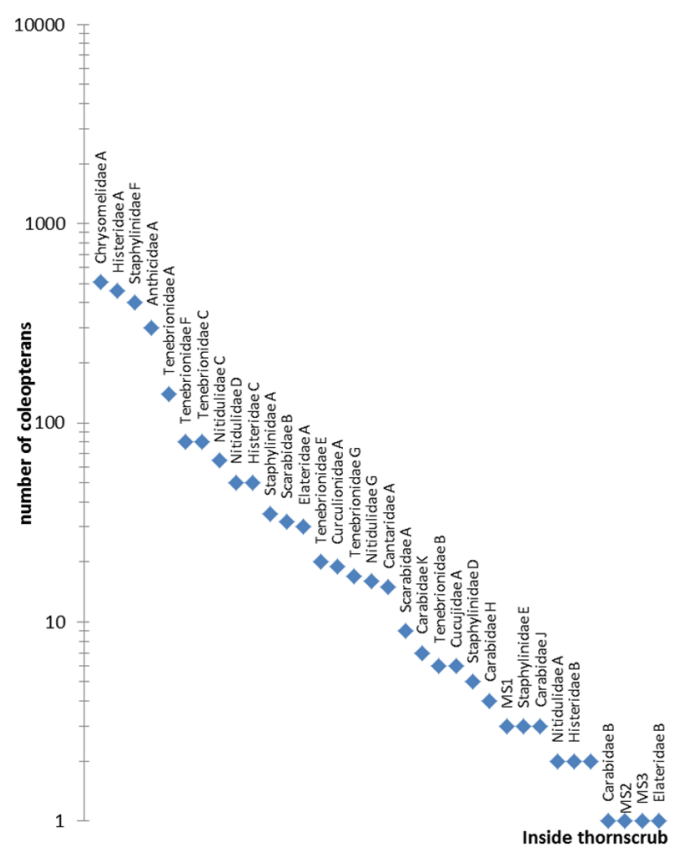

morphospecies (family Nitidulidae C). Whereas for insects found under trees inside remnant vegetation there were four co-dominant morphospecies (Chrysomelidae A, Histeridae A, Staphylinidae F and Anthicidae A).

\section{Discussion}

The higher beetle density found in isolated mesquites could be associated to the higher fruit and seed production in those trees (Cuellar, 1999). Isolated trees, perhaps with more available resources due to less competition may support larger insect populations in agreement with Abrams (1995) productive sites theory. For Texas ebonies in contrast, beetle density was not consistently higher for isolated trees or those inside remnant vegetation and the highest beetle density for isolated trees occurred from March to April, which coincides with bean and maize in surrounding agriculture.

For both tree species there was no difference in the number of beetle species in response to isolation. For isolated trees however, one insect family is dominant while for trees inside remnant vegetation four families are co-dominant. This is in agreement with Parmenter et al. (1991) findings of greater dominance found across disturbed ecosystems.

The relevance of habitat fragmentation in biodiversity and ecosystem functioning has been described as an area where theory is still ahead of empirical research (Tscharntke and Brandl, 2004). In our study we provide some empirical information that seems to be in agreement

Figure 3. Morphospecies composition of coleopterans found under trees inside remnant vegetation (left) and under isolated trees (right). The number of individuals for each morphospecies is plotted on a log scale. 
Table 1. Total number of the twenty-five most common beetles in isolated trees and trees inside a Tamaulipan thornscrub fragment. Numbers highlighted in gray represent the highest values either in isolated trees or in trees inside remnant thornscrub fragments.

\begin{tabular}{|c|c|c|c|c|c|c|c|c|c|c|c|c|}
\hline \multirow{2}{*}{ Family } & \multicolumn{2}{|c|}{ Apr. 2009} & \multicolumn{2}{|c|}{ Sept. 2009} & \multicolumn{2}{|c|}{ Nov. 2009} & \multicolumn{2}{|c|}{ Mar. 2010} & \multicolumn{2}{|c|}{ Apr. 2010} & \multicolumn{2}{|c|}{ Total } \\
\hline & Inside & Isolated & Inside & Isolated & Inside & Isolated & Inside & Isolated & Inside & Isolated & Inside & Isolated \\
\hline Anthicidae A & 118 & 45 & 25 & 18 & 33 & 58 & 11 & 22 & 14 & 55 & 301 & 198 \\
\hline Cantaridae A & 8 & 1 & 2 & 3 & 2 & 2 & 1 & 0 & 2 & 0 & 15 & 6 \\
\hline Carabidae B & 1 & 4 & 0 & 2 & 0 & 0 & 0 & 4 & 0 & 5 & 1 & 15 \\
\hline Chrysomelidae A & 128 & 18 & 34 & 15 & 21 & 17 & 223 & 8 & 104 & 12 & 510 & 70 \\
\hline Cucujidae A & 4 & 102 & 0 & 27 & 0 & 35 & 0 & 78 & 2 & 58 & 6 & 300 \\
\hline Curculionidae A & 5 & 1 & 8 & 2 & 3 & 0 & 2 & 0 & 1 & 1 & 19 & 4 \\
\hline Elateridae A & 15 & 7 & 8 & 0 & 2 & 0 & 0 & 1 & 5 & 0 & 30 & 8 \\
\hline Histeridae A & 147 & 487 & 78 & 405 & 65 & 259 & 116 & 527 & 54 & 322 & 460 & 2000 \\
\hline Histeridae C & 45 & 1 & 0 & 0 & 0 & 0 & 2 & 0 & 3 & 0 & 50 & 1 \\
\hline Nitidulidae A & 0 & 5 & 1 & 8 & 1 & 3 & 0 & 1 & 0 & 0 & 2 & 17 \\
\hline Nitidulidae C & 26 & 98 & 2 & 36 & 4 & 54 & 28 & 187 & 5 & 145 & 65 & 520 \\
\hline Nitidulidae D & 17 & 4 & 8 & 0 & 7 & 0 & 7 & 0 & 11 & 3 & 50 & 7 \\
\hline Nitidulidae G & 2 & 9 & 9 & 19 & 0 & 8 & 5 & 14 & 0 & 0 & 16 & 50 \\
\hline Scarabidae A & 6 & 9 & 0 & 8 & 0 & 9 & 3 & 8 & 0 & 6 & 9 & 40 \\
\hline Scarabidae B & 12 & 0 & 8 & 0 & 5 & 0 & 2 & 0 & 5 & 0 & 32 & 0 \\
\hline Staphylinidae A & 18 & 0 & 0 & 0 & 6 & 0 & 8 & 0 & 3 & 0 & 35 & 0 \\
\hline Staphylinidae C & 0 & 5 & 0 & 9 & 0 & 8 & 0 & 3 & 0 & 0 & 0 & 20 \\
\hline Staphylinidae D & 1 & 11 & 0 & 5 & 0 & 2 & 0 & 6 & 5 & 1 & 6 & 25 \\
\hline Staphylinidae F & 87 & 0 & 58 & 0 & 24 & 0 & 69 & 0 & 162 & 0 & 400 & 0 \\
\hline Tenebrionidae A & 16 & 5 & 8 & 4 & 2 & 9 & 36 & 2 & 78 & 0 & 140 & 19 \\
\hline Tenebrionidae B & 5 & 17 & 0 & 2 & 0 & 0 & 0 & 0 & 2 & 1 & 7 & 25 \\
\hline Tenebrionidae C & 23 & 18 & 8 & 11 & 18 & 0 & 11 & 6 & 20 & 4 & 80 & 39 \\
\hline Tenebrionidae E & 5 & 0 & 4 & 0 & 5 & 1 & 6 & 0 & 0 & 0 & 20 & 1 \\
\hline Tenebrionidae $\mathrm{F}$ & 26 & 8 & 5 & 9 & 1 & 5 & 46 & 7 & 2 & 10 & 80 & 39 \\
\hline Tenebrionidae G & 8 & 0 & 0 & 0 & 0 & 0 & 0 & 0 & 9 & 0 & 17 & 0 \\
\hline
\end{tabular}

with the importance of small habitats maximizing diversity (Demite et al., 2015; Tscharntke et al., 2002).

\section{Conclusion}

Insect density varied between dates but not between tree species. The total number of beetles under isolated trees and those immersed in remnant fragments was similar. There were more insects under isolated mesquites than under those immersed in remnant fragments. From the 72 morphospecies found, 52 occurred in both conditions although with different number of individuals. Four species occurred only in remnant fragments and were not found under isolated trees, and two had little representation in isolated trees. Five species occurred in large quantities under isolated trees. There was one dominant morphospecies (family Histeridae A) and one co-dominant morphospecies (family Nitidulidae C) under isolated trees. There were four co-dominant morphospecies (Chrysomelidae A, Histeridae A, Staphylinidae F and Anthicidae A) under trees inside remnant vegetation.

\section{Acknowledgements}

This research was supported by grants from PAICYT UANL and CONACYT

\section{References}

ABRAMS, P.A., 1995. Monotonic or unimodal diversity-productivity gradients: what does competition theory predict? Ecology, vol. 76, no. 7, pp. 2019-2127. http://dx.doi.org/10.2307/1941677.

ANTONIO-NEMIGA, X., TREVINO-GARZA, J. and JURADOYBARRA, E., 2008. Forest fragmentation in the sub watershed of the Pilon River: diagnostic and priorities. Madera y Bosques, vol. 14 , no. 3 , pp. $5-23$.

BROWN, K.S., 1997. Diversity, disturbance, and sustainable use of Neotropical forests: insects as indicators for conservation monitoring. Journal of Insect Conservation, vol. 1, no. 1, pp. 25-42. http://dx.doi.org/10.1023/A:1018422807610.

CUELLAR, L.G., 1999. Efecto de la fragmentación del matorral tamaulipeco en la diversidad y densidad de coleópteros y en la producción de semillas. San Nicolás de Los Garza: Universidad Autónoma de Nuevo León, 85 p. Disertación de Maestrado em Ciências Florestais.

DEMITE, P.R., FERES, R.J.F. and LOFEGO, A.C., 2015. Influence of agricultural environment on the plant mite community in forest fragments. Brazilian Journal of Biology = Revista Brasileira de Biologia, vol. 75, no. 2, pp. 396-404. http://dx.doi.org/10.1590/15196984.14913. PMid:26132024.

DIDHAM, R.K., GHAZOUL, J., STORK, N.E. and DAVIS, A.J., 1996. Insects in fragmented forests: a functional approach. 
Trends in Ecology \& Evolution, vol. 11, no. 6, pp. 255-260. http:// dx.doi.org/10.1016/0169-5347(96)20047-3. PMid:21237834.

FAHRIG, L., 2002. Effect of habitat fragmentation on the extinction threshold: a synthesis. Ecological Applications, vol. 12, no. 2, pp. 346-353.

FOROUGHBAKHCH, R., ALVARADO-VÁZQUEZ, M.A., PARRA, A.C., HERNÁNDEZ-PIÑERO, J.L. and LUCIO, G., 2013. Diversidad florística de un área dominada por arbustos en el Noreste de México. Phyton, vol. 82, no. 2, pp. 175-184.

HIRAO, T., MURAKAMI, M. and KASHIZAKI, A., 2008. Effects of mobility on daily attraction to light traps: comparison between lepidopteran and coleopteran communities. Insect Conservation and Diversity, vol. 1, no. 1, pp. 32-39. http://dx.doi. org/10.1111/j.1752-4598.2007.00004.x.

HUNTER, M.D., 2002. Landscape structure, habitat fragmentation, and the ecology of insects. Agricultural and Forest Entomology, vol. 4, no. 3, pp. 159-166. http://dx.doi.org/10.1046/j.14619563.2002.00152.x.

INSTITUTO NACIONAL DE ESTADÍSTICA Y GEOGRAFÍAINEGI, 2008. Manual de características edafológicas y fisiográficas de México. Aguascalientes: INEGI.

JURADO, E., CUELLAR, G., FLORES, M., GONZALEZ, I., AGUIRRE-BRAVO, C. and FRANCO, C.R., 1999. Biodiversity of tamaulipan thornscrub in relation to fragmentation. In: USDA Forest Service Proceedings RMRS-P-12, 2-6 November 1999, Guadalajara, México. Fort Collins: U.S. Department of Agriculture, Forest Service, Rocky Mountain Research, pp. 272-275.

JURADO, E., FLORES, J., ENDRESS, A., FLORES, M., ESTRADA, E. and PANDO, M., 2006a. Seed removal rates under isolated trees and continuous vegetation in semiarid thornscrub. Restoration Ecology, vol. 14, no. 2, pp. 204-209. http://dx.doi. org/10.1111/j.1526-100X.2006.00122.x

JURADO, E., GARCÍA, J.F., FLORES, J. and ESTRADA, E., 2006b. Leguminous seedling establishment in Tamaulipan thornscrub of Northeastern Mexico. Forest Ecology and Management, vol. 221, no. 1-3, pp. 133-139. http://dx.doi.org/10.1016/j.foreco.2005.09.011

LAURANCE, W.F., FERREIRA, L.V., MERONA, J.M.R-D., LAURANCE, S.G., HUTCHINGS, R.W. and LOVEJOY, T.E., 1998. Effects of forest fragmentation on recruitment patterns in Amazonian tree communities. Conservation Biology, vol. 12, no. 2, pp. 460-464. http://dx.doi.org/10.1046/j.1523-1739.1998.97175.x.

MALCOLM, J.R., 1994. Edge effects in central Amazonian forest fragments. Ecology, vol. 75, no. 8, pp. 2438-2445. http://dx.doi. org/10.2307/1940897.
PARMENTER, R.R., MACMAHON, J.A. and GILBERT, C.A.B., 1991. Early successional patterns of arthropod recolonization on reclaimed wyoming strip mines: the grasshoppers (Orthoptera: Acrididae) and allied faunas (Orthoptera: Gryllacrididae, Tettigoniidae). Environmental Entomology, vol. 20, no. 1, pp. 135-142. http://dx.doi.org/10.1093/ee/20.1.135.

REID, N., MARROQUÍN, J. and BEYER-MÜNZEL, P., 1990b. Utilization of shrubs and trees for browse, fuelwood and timber in the Tamaulipan thornscrub, northeastern Mexico. Forest Ecology and Management, vol. 36, no. 1, pp. 61-79. http://dx.doi. org/10.1016/0378-1127(90)90064-I.

REID, N., STAFFORD, S.D., BEYER-MÜNZEL, P. and MARROQUÍN, J., 1990a. Floristic and structural variation in the Tamaulipan thornscrub, northeastern Mexico. Journal of Vegetation Science, vol. 1, no. 4, pp. 529-538. http://dx.doi. org/10.2307/3235787.

SCARIOT, A., 1999. Forest fragmentation effects on palm diversity in central Amazonia. Journal of Ecology, vol. 87, no. 1, pp. 66-76. http://dx.doi.org/10.1046/j.1365-2745.1999.00332.x.

SILVA, D.J., SANTOS-FILHO, M. and CANALE, G.R., 2014. The importance of remnant native vegetation of Amazonian submontane forest for the conservation of lizards. Brazilian Journal of Biology $=$ Revista Brasileira de Biologia, vol. 74, no. 3, pp. 523-528. http://dx.doi.org/10.1590/bjb.2014.0095. PMid:25296198.

TSCHARNTKE, T. and BRANDL, R., 2004. Plant-insect interactions in fragmented landscapes. Annual Review of Entomology, vol. 49, no. 2, pp. 405-430. http://dx.doi.org/10.1146/annurev. ento.49.061802.123339. PMid:14651470.

TSCHARNTKE, T., SEKERCIOGLU, C.H., DIETSCH, T.V., SODHI, N.S., HOEHN, P. and TYLIANAKIS, J.M., 2008. Landscape constraints on functional diversity of birds and insects in tropical agroecosystems. Ecology, vol. 89, no. 4, pp. 944-951. http://dx.doi.org/10.1890/07-0455.1. PMid:18481519.

TSCHARNTKE, T., STEFFAN-DEWENTER, I., KRUESS, A. and THIES, C., 2002. Characteristics of insect populations on habitat fragments: a mini review. Ecological Research, vol. 17, no. 2, pp. 229-239. http://dx.doi.org/10.1046/j.1440-1703.2002.00482.x.

WETTSTEIN, W. and SCHMID, B., 1999. Conservation of arthropod diversity in montane wetlands: effect of altitude, habitat quality and habitat fragmentation on butterflies and grasshoppers. Journal of Applied Ecology, vol. 36, no. 3, pp. 363-373. http:// dx.doi.org/10.1046/j.1365-2664.1999.00404.x. 